This manuscript is contextually identical with the following published paper:

Árpád Ferincz; Ádám Staszny; András Weiperth; Péter Takács; Béla Urbányi; Lorenzo

Vilizzi; Gábor Paulovits; Gordon H. Copp (2016) Risk assessment of non-native fishes in the catchment of the largest Central-European shallow lake (Lake Balaton, Hungary).

Hydrobiologia 780, pp 85-97. DOI: 10.1007/s10750-016-2657-2

The original published PDF available in this website:

http://dx.doi.org/10.1007/s10750-016-2657-2

\title{
Risk assessment of non-native fishes in the catchment of the largest Central-European shallow lake (Lake Balaton, Hungary)
}

\author{
Árpád Ferincz ${ }^{1}$, Ádám Staszny ${ }^{1}$, András Weiperth ${ }^{2}$, Péter Takács ${ }^{3}$, Béla Urbányi ${ }^{1}$, Lorenzo \\ Vilizzi $^{4}$, Gábor Paulovits ${ }^{3}$, Gordon H. Copp ${ }^{5}$ \\ ${ }^{1:}$ Department of Aquaculture, Faculty of Agricultural and Environmental Sciences, Szent \\ István University, H-2100 Gödöllő, Páter K. str. 1. \\ 2: Danube Research Institute, Centre for Ecological Research, Hungarian Academy of \\ Sciences, 1113 Budapest Karolina str. 29.
}

3: Balaton Limnological Institute, Centre for Ecological Research, H-8237 Tihany Klebelsberg K. str. 3.

\footnotetext{
4: Faculty of Fisheries, Mugla Sıtkı Koçman University, 48000 Kötekli, Muğla, Turkey

5: Centre for Environment, Fisheries \& Aquaculture Science, Lowestoft, Suffolk, NR33 0HT, UK; and Department of Life and Environmental Sciences, Bournemouth University, Poole, UK; and Environmental and Life Sciences Graduate Program, Trent University, Peterborough, Canada.
} 


\section{Abstract}

The Fish Invasiveness Screening Kit (FISK) has proved to be a useful tool for assessing and screening the risk posed by potentially invasive fish species in larger risk assessment (RA) areas (i.e. country or multi-country level). In the present study, non-native freshwater fishes were screened for a smaller RA area, the closed and vulnerable but economically important drainage basin of Lake Balaton (Hungary). Receiver operator characteristic analysis of FISK scores for 26 fish species screened by four assessors identified 21 species with scores of $\geq 11.4$ to pose a 'high risk' of being invasive, with five species ranked as 'medium risk' and none as 'low risk'. The highest scoring species were gibel carp Carassius gibelio and black bullhead Ameiurus melas, with three Ponto-Caspian Gobiidae identified as amongst the species posing the potentially greatest threat to the catchment. The results of the present study indicate that FISK can be applied to risk assessment areas of smaller geographical scale.

Keywords: FISK, shallow lakes, invasibility, hazard identification, biological invasions 


\section{Introduction}

Lake Balaton is the largest shallow lake in Central Europe. The lake and its catchment are considered to be one of the most economically important regions of Hungary, providing essential ecosystem services such as angling tourism, which has increased continuously across the catchment. The populations of target native species, i.e. common carp Cyprinus carpio and pikeperch Sander lucioperca, are strongly dependent upon the stocking of non-native species (Specziár and Turcsányi 2014). Also, the opening of the Sió Canal in the 1860s connected the Balaton basin with that of the River Danube (Korponai et al. 2010; Zlinszky and Tímár 2013), resulting in several biological invasions (Bíró 1972; Muskó et al. 2008; Benkő-Kiss et al. 2013).

Based on the list of native species given in Herman (1887), the first non-native fish to have invaded the Balaton basin (via the Sió Canal) was tubenosed goby Proterorhinus semilunaris, which is native to the lower Danube, followed by introductions in the late 19th century of three North American fishes, pumpkinseed Lepomis gibbosus, rainbow trout Oncorhynchus mykiss and mosquitofish Gambusia affinis, and also European eel Anguilla anguilla. These species were introduced for aquaculture (rainbow trout, eel), ornamental purposes (pumpkinseed) and mosquito control (Herman 1890; Vutskits 1897; Györe 1995). Being intolerant to colder temperatures, the mosquitofish has not dispersed from its original introduction site, the thermal lake at Héviz (Specziár 2004). The next wave of introductions to Lake Balaton occurred in the 1960s and involved several species of Far-Eastern origin. At present, 12 of the 42 fish species (29\%) in the Balaton catchment are non-native (Takács et al. 2011), which is amongst the highest in Europe (Economidis et al. 2000; Copp et al. 2005a; Povz and Sumer 2006; Koščo et al. 2010; Lusk et al 2010; Almeida et al. 2013).

The distribution, abundance and related impact on the native ecosystem by these non-native species varies strongly even at local geographical scales (Erős et al. 2009; Sály et al. 2011; 
Ferincz et al. 2012, 2014; Paulovits et al. 2014), and the possibility of further introductions is still high. For this reason, there is an urgent need to identify those species that are likely to pose a high risk to the Balaton catchment. The aims of the present study were therefore to: 1) undertake a risk screening of non-native species using version 2 (Lawson et al. 2013) of the Fish Invasiveness Screening Kit (FISK; Copp et al. 2009) so as to inform environmental managers of which non-native species pose the greatest risk of being invasive in the Balaton catchment; and 2) evaluate the applicability of FISK to smaller risk assessment (RA) areas than those (country or regional scales) for which it has been used in the past (Copp 2013).

\section{Material and Methods}

The RA area, the Lake Balaton catchment (Fig. 1), is located in West Hungary (Transdanubia), has an area of $5775 \mathrm{~km}^{2}$ and is characterized by a humid continental climate (Köppen-Geiger type Dfb: Peel et al. 2007). The Balaton catchment supports stable populations of several species listed in the Bern Convention (Annexes II and III) and Habitats Directive (Annexes II, IV and V), such as razorfish Pelecus cultratus, asp Aspius aspius, Volga pikeperch Sander volgensis and the endemic European mudminnow Umbra krameri (Specziár et al. 2010, Takács et al. 2015).

Altogether, 26 non-native species were assessed for their potential to represent a threat for the RA area using FISK v2 (Lawson et al. 2013), and their selection was based on the following two criteria: 1) the species has already been reported from the Balaton catchment (Takács et al. 2011); and 2) the species occurs within the territory of Hungary (Harka and Sallai 2004; Halasi-Kovács et al. 2011), which is taken to represent the primary donor area. Of the species assessed, $12(46 \%)$ corresponded to criterion 1 and $14(54 \%)$ to criterion 2 (Table 1).

FISK v2 (Lawson et al. 2013) was chosen because of its widespread usage, relative simplicity and 'policy-maker friendly' output (Copp 2013). Briefly, FISK v2 relies on 49 questions in 
total that assess the potential risk of a species being invasive and are arranged according to eight topics: domestication/cultivation, climate and distribution, invasive elsewhere, undesirable traits, feeding guild, reproduction, dispersal mechanism, and persistence attributes. Importantly, in this study definition of the RA area (the Lake Balaton catchment) was based on biogeography considerations instead of political boundaries (as done for most previous FISK applications), and this is consistent with non-native species risk analysis guidelines (e.g. EPPO 2002) and more generally agrees with the non-native species concept (Copp et al. 2005b).

Assessments of the 26 species were carried out independently by four assessors (AF, AS, AW and PT), who have knowledge of the distribution and ecology of fishes within the risk assessment area. Receiver operating characteristic (ROC) curves analysis was used to assess the predictive ability of the FISK tool, with the final objective to determine a threshold score for discriminating between non-invasive and invasive species. Since $a$ priori categorization of the species is needed for this test, FishBase (http://www.fishbase.org/home.htm) and the database of Invasive Species Specialist Group (http://www.issg.org/) were used to categorise the species a priori as 'invasive' or 'non-invasive'. Four independent ROC curves were then constructed for the four assessors, and differences between these curves were statistically assessed using the Venkatraman (2000) method. Following between-curve comparison, a global ROC curve was computed on the mean scores from all 26 species evaluated.

Statistically, a ROC curve is a graph of sensitivity versus 1 minus specificity ( 1 - specificity), and in the present context the sensitivity of the FISK test will be the proportion of invasive fish species that are correctly identified by the test, whereas specificity refers to the proportion of non-invasive species that are correctly identified as such. An important measure of the accuracy of the calibration analysis is the area under the ROC curve. If this area is equal to 1.0, then the ROC curve consists of two straight lines, one vertical from 0.0 to 0.1 and the 
next horizontal from 0.1 to 1.1 . In such cases, the test is $100 \%$ accurate because both the sensitivity and specificity are 1.0 , so there are no false positives or false negatives. On the other hand, a test is not accurate if the ROC curve is a diagonal line from 0.0 to 1.1 . The ROC area for this line is 0.5 , with ROC curve areas typically being between 0.5 and 1.0 (Copp et al. 2009). The best FISK threshold (cut-off) value that maximizes the true positive rate (true invasive classified as invasive) and minimizes the false positive rate (true non-invasive classified as invasive) was determined using a combination of Youden's J statistic (Youden 1950) and the point closest to the top-left part of the plot with perfect sensitivity or specificity. For the global (mean) ROC curve, a smoothed mean ROC curve was also generated and bootstrapped confidence intervals of specificities computed along the entire range of sensitivity points ( 0 to 1 , at 0.1 intervals).

As each response of FISK for a given species is allocated a certainty score $(1=$ very uncertain; 2 = mostly uncertain; $3=$ mostly certain; $4=$ very certain), a 'certainty factor' (CF) was computed as:

$$
\Sigma\left(\mathrm{CQ}_{i}\right) /(4 \times 49)(i=1, \ldots, 49)
$$

where CQ $i$ is the certainty for question $i, 4$ is the maximum achievable value for certainty (i.e. 'very certain') and 49 is the total number of questions comprising the FISK tool. The CF therefore ranges from a minimum of 0.25 (i.e. all 49 questions with certainty score equal to 1 ) to a maximum of 1 (i.e. all 49 questions with certainty score equal to 4). Analyses were carried out with package pROC for R statistical environment (R Development Core Team 2015, Robin et al. 2011) and 2000 bootstrap replicates were used.

\section{Results}

There were no statistical differences between the four assessor-specific ROC curves and corresponding AUCs (Venkatraman permutation tests: Table 1, Fig 2a). As a result, a global ROC curve could be computed based on mean FISK scores, which resulted in an AUC of 
0.7005 (0.5226-0.9224 95\% CI), hence above 0.5 (Fig. 2b). This indicated that FISK was able to discriminate reliably between invasive and non-invasive species for the Balaton catchment. Since Youden's $J$ and closest top-left statistics provided slightly different values (i.e. $\approx 11.4$ and $\approx 11.9$, respectively), the smallest one was chosen as calibration threshold of the FISK risk outcomes for the Balaton catchment (Table 2). Based on this threshold,'medium risk' species were regarded as those with scores within the interval $[1 ; 11.4[$ and 'high risk sensu lato' species those with scores within the interval $[11.4 ; 57]$, with the latter further categorised as per Britton et al. (2010a) into 'moderately high risk' (interval [11.4, 25[), 'high risk' (interval $[25,30[$ ), and'very high risk' (interval $[30,57]$ ). Species categorised as 'low risk' were those attributed a FISK score within the interval [-15, 1[ (NB: open square brackets indicate an open interval).

Based on the 11.4 threshold score and corresponding intervals, none of the mean scores for the 26 species fell into the 'low risk' category, whereas five $(19.2 \%)$ were categorized as 'medium risk', and the remaining $21(80.7 \%)$ as 'high risk' sensu lato of which 18 (85.7\%, $69.2 \%$; of total) as 'moderately high risk', two $(9.5 \% ; 7.4 \%$ of total) as 'high risk' (topmouth gudgeon Pseudorasbora parva and black bullhead Ameiurus melas), and one (4.8\%; 3.7\% of the total) as 'very high risk' (gibel carp Carassius gibelio; Table 2). The lowest-scoring species was the rainbow chichlid Archrocentrus multispinosus.

Mean and median scores according to the different selection criteria showed significant differences $(t=-3.48, \mathrm{df}=99.9, P=0.0007)$, with non-native species already inhabiting the catchment scoring higher. Amongst the Criterion 1 species, the highest scoring were the round goby Neogobius melanostomus, bighead goby Ponticola kessleri, and the racer goby Babka gymnotracheus. The median FISK score in each group (i.e. criteria 1 and 2) was higher than the 11.4 threshold (Fig. 3). Mean scores for all species classified a priori as invasive were ranked as 'high risk sensu lato' and fell into the 'moderately high risk' sub-category. 
However, the mean scores for non-invasive species both of least concern and vulnerable threat status also were ranked as 'moderately high risk', with only the non-invasive endangered Siberian sturgeon Acipenser baeri classified as 'medium risk' (Fig. 4).

Mean certainty in response for all species was $3.36 \pm 0.3$ SE (i.e. above the category "mostly certain") and CF was $0.84 \pm 0.09 \mathrm{SE}$, and ranged from a minimum of $2.52 \pm 0.1 \mathrm{SE}$ (CF: 0.63 $\pm 0.01 \mathrm{SE}$ ) for channel catfish Ictalurus punctatus and rainbow trout to a maximum of $3.88 \pm$ 0.4 SE (CF: $0.97 \pm 0.08 \mathrm{SE}$ ) for monkey goby Neogobius fluviatilis and round goby (Table 1).

\section{Discussion}

The threshold value of 11.4 obtained in the present study was overall consistent with those for previous FISK-based assessments in neighbouring areas, namely the southern (threshold = 9.5: Simonović et al. 2013) and northern (threshold= 11.8: Piria et al. 2015) Balkans countries. Conversely, the Lake Balaton FISK threshold value was lower than those obtained for RA areas elswhere worldwide, ranging from 15.3 to 24 (Copp et al. 2009; Verreycken et al. 2009; Onikura et al. 2011; Vilizzi and Copp 2012; Almeida et al. 2013; Puntila et al. 2013; Tarkan et al. 2014; Perdikaris et al. 2015; Mendoza et al. 2015). The lower threshold values in the Balkans region, where within-region and/or between-catchment translocations have occurred, has been attributed to the elevated proportion of endemic species (Simonović et al. 2013; Piria et al. 2015). Locally translocated species (those native to one part of the RA area and introduced outside their native range within the RA area) tend to be less invasive than more exotic species (those from other continents), and this is likely the reason for the lower threshold values. The reason for the low score threshold in the Balaton catchment could be attributed to a scale-dependent effect, given that this RA area is much smaller than the RA areas of previous FISK applications, where entire countries, regions, or very large river catchments were considered (Copp 2013). 
The taxonomic profiles of the highest scoring species showed overall similarities to previous studies, with cyprinids and ictalurid catfishes being ranked as high risk (Mastitisky et al. 2010; Almeida et al. 2013; Puntila et al. 2013; Tarkan et al. 2014; Perdikaris et al. 2015; Piria et al. 2015). Gibel carp received the highest score, similar to FISK assessments elsewhere in Europe and Asia Minor. This species, native to the Far East (Bănărescu 1990), has a long history of invasiveness and its establishment in the Danube system could have occurred in two ways. Firstly, Holčík (1980) hypothesised that gibel carp expand across Romania by natural dispersal, but (secondly) stocks were also known to have been imported previously from Bulgaria to Szarvas (Eastern Hungary) for aquaculture (Szalay 1954). The first report of gibel carp for the Hungarian section of the Danube was in 1975 (Tóth 1975), with its introduction to Lake Balaton occurred in the same period (Bíró 1997), and the species is currently present virtually throughout the Balaton catchment, with extemely high abundances in wetlands, angling ponds and canals (Ferincz et al. 2016).

Black bullhead scored second highest in the present study. With the exception of Finland (Puntila et al. 2013), this high risk ranking is consistent with FISK assessments elsewhere, including Europe (Copp et al. 2009; Verreycken et al. 2009; Mastitsky et al. 2010; Almeida et al. 2013; Perdikaris et al. 2015; Piria et al 2015), Asia Minor (Tarkan et al. 2014) and the Murray-Darling basin, Australia (Vilizzi and Copp 2012). Tolerant of harsh water conditions (e.g. pollution, low dissolved oxygen levels), this nest-guarding species is omnivorous and aggressive (Braig and Johnson 2003; Novomenská and Kováč 2009). Black bullhead was first reported in Europe, in France, in 1871, where it was imported for aquaculture (Coucherousset et al. 2006), and it has since expanded its invasive range to become the most widespread North American ictalurid catfish of Europe (Pedicillo et al. 2008). The species' expansion has been human mediated and fast in some cases (e.g. to Hungary from Italy in 1980: Harka 1997). In other European locations, however, dispersal has been slower, such as in Spain (first 
record in 1984: Elvira 1984), Portugal (first record in 2002; Gante and Santos 2002), and England, where the only recently confirmed population has been present for $>50$ years (Wheeler et al. 2004) but was eradicated in 2014 (GB Non-native Species Secretariat 2014). Yeü, despite achieving a high score, its abundance and frequency of occurrence is still generally low across the Balaton catchment (Erős et al. 2009; Sály et al. 2011; Paulovits et al. 2014; Ferincz et al. 2015).

Topmouth gudgeon was also categorised as 'high risk', similar to all other European and Asia Minor assessments. This small, mainly planktivorous fish, which is regarded as the most invasive species in Europe (Gozlan et al. 2005, 2010), is native to the Far East (i.e. China, Korea and western regions of Japan, and its introduction to Europe (including Hungary) and Middle Asia occurred accidentally in 1960-1962 as a contaminant of larvae of large herbivorous cyprinids (i.e. Hyphophthalmichtys sp. and grass carp Ctenopharyngodon idella) imported to Romania from China (Bănărescu 1964). A continental-scale invasion then took place in the 1970-80s, and currently the species is widespread throughout Europe (Gozlan et al. 2010). Extremely high abundances are often found in small angling ponds, nursing ponds and canals of pond aquaculture facilities (Adamek and Siddiqui 1997; Rosecchi et al. 2001; Britton et al. 2010b), and there is increasing evidence of its impacts on native fishes (e.g. Britton et al. 2007, 2009, 2011; Gozlan et al. 2005, 2010). For example, competition for spawning grounds with the endangered Pseudorasbora pumila has been observed in Japan (Konishi and Takata 2004) and trophic overlaps with roach Rutilus rutilus and rudd Scardinius erythrophthalmus have been reported (Britton et al. 2010c). Specific to the Balaton catchment, topmouth gudgeon is found in every habitat with the highest abundances recorded in angling and fish ponds (Sály et al. 2011; Paulovits et al. 2014; Ferincz et al. 2015).

According to current assessment, the Amur sleeper Percottus glenii was categorised as 'moderately high risk', in spite of recent studies having highlighted this species as the most 
threatening for the native fish communities of the Carpathian Basin (Kati et al. 2015; Takács et al. 2015). Currently, the status of this species is confusing, as it is classed as 'Vulnerable' in its native range, but also considered to be the most invasive species in Central Europe. The invasion of this small odontobutid (Perciformes: Odontobutidae) species is well documentated (Terlecki and Palka 1999; Harka and Sallai 1999; Koščo et al. 2003; Nalbant et al. 2004; Reshetnikov 2004; Simonović et al. 2006; Jurajda et al. 2006; Nowak et al. 2008), and its native range is the Russian Far East and the northern part of the Korean Penninsula and the potential Holarctic distribution was modelled by Reshetnikov and Ficetola (2011). The introduction and expansion of Amur sleeper in Europe started with two introduction events, namely in St. Petersburg in 1912 and Moscow in 1948, both as releases from aquaria (Koščo et al. 2003). The first Hungarian specimen of the Amur sleeper was collected in 1997 in the middle section of the River Tisza (Harka 1998), and the species has since invaded the highly-vegetated irrigation canals, oxbow lakes and other lentic habitats of the river catchment (Harka and Sallai 1999). At the time, the species was expected to require decades to reach the Transdanubian region (Erös et al. 2008). However, the first specimens were caught in the Balaton-catchment in 2008 (Erös et al. 2008) and reached the mouth of the main inflow of River Zala in 2012 (Takács et al. 2012). As the Amur sleeper has been known to extirpate populations of the endemic, strictly-protected European mudminnow (Kati et al. 2015, Takács et al. 2015) and amphibians, aquatic macroinvertebrates (Reshetnikov 2003, 2008). Therefore, the effective risk posed by this non-native species is considered to be higher than indicated by the current risk assessment.

Similarly to Turkey (Tarkan et al. 2014), the Iberian Peninsula (Almeida et al. 2013), Greece (Perdikaris et al. 2015) and Northern Balkan countries (Piria et al. 2015), no species in the present study were categorised as at 'low risk' of being invasive. This finding is in agreement with the 'invasion sensitivity' of this small and closed catchment (Bíró 1972; 
Muskó et al. 2008; Benkő-Kiss et al. 2013). The significantly higher scores of the species already present in the catchment indicated that species with higher invasive potential are already present in the RA area. In this respect, the potentially most threatening species were those from Criterion 2, and included three Ponto-Caspian gobies (i.e. round goby, racer goby, bighead goby). These species have a long invasion history throughout Europe and North America (Kornis et al. 2012; Roche et al. 2013), and the Sió Canal may represent an important invasion corridor from river Danube. For this reason, appropriate management measures are required of the Sió floodgate to prevent the passage of this species into Lake Balaton.

In conclusion, a succesful risk screening was carried out for the small and isolated catchment of Lake Balaton. The most threatening non-native species were identified using FISK v2. These results pointed out the necessity and possibility of damming further invasions and might be a basis of planning the further fish stock management issues of the RA area.

\section{Acknowledgements}

This study was supported by the Research Centre of Excellence-9878/2015/FEKUT. Gábor Paulovits was supported by the EuLakes Project (Central Europe Programme).

\section{References}

Adamek, Z. \& M. A. Siddiqui, 1997. Reproduction parametres in a natural population of topmouth gudgeon, Pseudorasbora parva, and its condition and food characteristics with respect to sex dissimilarities. Polish Archives of Hydrobiology 44: 145-152.

Almeida, D., F. Ribeiro, P. M. Leunda, L. Vilizzi \& G. H. Copp, 2013. Effectiveness of FISK, an invasiveness screening tool for non-native freshwater fishes, to perform risk identification assessments in the Iberian Peninsula. Risk Analysis 33: 1404-1413. 
Bănărescu, P., 1964. Pisces - Osteichthyes. Fauna Republicii Populare Romine, 13th edn. Acad. RPR, Bucuresti, 959 pp. [In Romanian]

Bănărescu P., 1990. Distribution and dispersal of freshwater animals in North America and Eurasia. Wiesbaden: Aula-Verlag, Zoogeography of Freshwaters: 91-92.

Benkő-Kiss, Á., Á. Ferincz, N. Kováts \& G. Paulovits, 2013. Spread and distribution pattern of Sinanodonta woodiana in Lake Balaton. Knowledge and Management of Aquatic Ecosystems 408: 1-7.

Bíró, P., 1972. Neogobius fluviatilis in Lake Balaton—a Ponto-Caspian goby new to the fauna of central Europe. Journal of Fish Biology 4: 249-255.

Bíró, P., 1997. Temporal variation in Lake Balaton and its fish population. Ecology Of Freshwater Fish 6: 196-216.

Braig, E. C. \& D. L. Johnson, 2003. Impact of black bullhead (Ameiurus melas) on turbidity in a diked wetland. Hydrobiologia 490: 11-21.

Britton, J. R., G. D. Davies, M. Brazier \& A. C. Pinder, 2007. A case study on the population ecology of a topmouth gudgeon Pseudorasbora parva population in the UK and the implications for native fish communities. Aquatic Conservation 17: 749-759.

Britton, J. R., G. D. Davies \& C. Harrod, 2009. Trophic interactions and consequent impacts of the invasive fish Pseudorasbora parva in a native aquatic foodweb: a field investigation in the UK. Biological Invasions 12: 1533-1542.

Britton J. R., J. Cucherousset, G. D. Davies, M. J. Godard \& G. H. Copp, 2010a. Non-native fishes and climate change: predicting species responses to warming temperatures in a temperate region. Freshwater Biology 55: 1130-1141.

Britton, J. R., J. Cucherousset, J. Grey \& R. E. Gozlan, 2011. Determining the strength of exploitative competition from an introduced fish: roles of density, biomass and body size. Ecology of Freshwater Fish 20: 74-79. 
Britton, J. R., G. D. Davies \& M. Brazier, 2010b. Towards the successful control of the invasive Pseudorasbora parva in the UK. Biological Invasions 12: 125-131.

Britton, J. R., G. D. Davies \& C. Harrod, 2010c. Trophic interactions and consequent impacts of the invasive fish Pseudorasbora parva in a native aquatic foodweb: a field investigation in the UK. Biological Invasions 12: 1533-1542.

Copp, G. H., 2013. The Fish Invasiveness Screening Kit (FISK) for non-native freshwater fishes - a summary of current applications. Risk Analysis 33: 1394-1396.

Copp, G. H., P. G. Bianco, N. G. Bogutskaya, T. Erös, I. Falka, M. T. Ferreira, M. G. Fox, J. Freyhof, R. E. Gozlan, J. Grabowska, V. Kováč, R Moreno-Amich, A. M. Naseka, M. Peňáz, M. Povž, M. Przybylski, M. Robillard, I. C. Rusell, S. Stakènas, S. Šumer, A. VilaGispert \& C. Wiesner, 2005a. To be or not to be, a non-native freshwater fish? Journal of Applied Ichthyology 21: 242-262.

Copp, G. H., R. Garthwaite \& R. E. Gozlan, 2005b. Risk identification and assessment of non-native freshwater fishes: concepts and perspectives on protocols for the UK. Cefas Science Technical Report. Cefas, Lowestoft, 36 pp. (http://www.cefas.co.uk/publications/techrep/tech129.pdf) (accessed: 11 Jan. 2016)

Copp, G. H., S. Stakénas \& P. I. Davison, 2006. The incidence of nonnative fishes in water courses: Example of the United Kingdom. Aquatic Invasions 1: 72-75.

Copp, G. H., L. Vilizzi, J. Mumford, G. V. Fenwick, M. J. Godard \& R. E. Gozlan, 2009. Calibration of FISK, an invasiveness screening tool for non-native freshwater fishes. Risk Analysis 29: 457-467.

Coucherousset, J., J. M. Paillisson, A. Carpentier, M. C. Eybert \& J. D. Olden, 2006. Habitat use of an artificial wetland by the invasive catfish Ameiurus melas. Ecology of Freshwater Fish 15: 589-596. 
Economidis, P. S., E. Dimitriou, R. Pagoni, E. Michaloudi \& L. Natsis, 2000. Introduced and translocated fish species in the inland waters of Greece. Fisheries Management and Ecology 7: 239-250.

Elvira, B., 1984. First record of the North American catfish Ictalurus melas (Rafinesque, 1820) (Pisces, Ictaluridae) in Spanish waters. Cybium 8: 96-98.

EPPO, 2002. EPPO Standards. Pest Risk Analysis. PM 5/2 (revised). EPPO Bulletin 32: 231233.

Erős, T., A. Specziár \& P. Bíró, 2009. Assessing fish assemblages in reed habitats of a large shallow lake-A comparison between gillnetting and electric fishing. Fisheries Research 96: 70-76.

Erős, T., P. Takács, P. Sály, A. Specziár, Á. I. György \& P. Bíró, 2008. Az amurgéb (Percottus glenii Dybowski, 1877) megjelenése a Balaton vízgyüjtőjén. [First occurrence of Amur sleeper (Percottus glenii Dybowski, 1877) int he Balaton-catchment] Halászat 101: 75-77. (in Hungarian)

Ferincz Á, Zs. Horváth, Á. Staszny, A. Ács, N. Kováts, C. F. Vad, J. Csaba, S. Sütő \& G. Paulovits, 2016. Desiccation frequency drives local invasions of non-native gibel carp (Carassius gibelio) in the catchment of a large, shallow lake (Lake Balaton, Hungary). Fisheries Research 173: 37-44.

Ferincz, Á., Á. Staszny, A. Ács, A. Weiperth, I. Tátrai \& G. Paulovits, 2012. Long-term development of fish assemblage in Lake Fenéki (Kis-Balaton Water Protection System, Hungary): succession, invasion and stabilization. Acta Zoologica Scientarum Academiae Hungarica 58 (Supplementum 1): 3-18.

Ferincz, Á., Á. Staszny, A. Weiperth, S. Sütő, G. Soczó, A. Ács, N. Kováts \& G. Paulovits, 2014. Adatok a Dél-Balatoni berekterületek halfaunájához. [Data to the fish fauna of 
southern wetlands of Lake Balaton] Natura Somogyiensis 24: 279-286. (in Hungarian with English summary)

Gante, H. F. \& C. D. Santos, 2002. First records of North American catfish Ictalurus melas (Rafinesque, 1820) in Portugal. Journal of Fish Biology 61: 1643-1646.

GB Non-native Species Secretariat, (2014) High risk species eradicated from GB: Black bullhead catfish Ameiurus melas. (www.nonnativespecies.org/news/index.cfm?id=151) (last accessed: 22/07/2014)

Gozlan, R. E., D. Andreou, T. Asaeda, K. Beyer, R. Bouhadad, D. Burnard, N. Caiola, P. Cakic, V. Djikanovic, H. R. Esmaeili, I. Falka, D. Golicher, A. Harka, G. Jeney, V. Kováč, J. Musil, A. Nocita, M. Povž, N. Poulet, T. Virbickas, C. Wolter, A. S. Tarkan, E. Tricarico, T. Trichkova, H. Verreycken, A. Witkowski, C-g. Zhang, I. Zweimueller \& J. R. Britton, 2010. Pan-continental invasion of Pseudorasbora parva: towards a better understanding of freshwater fish invasions. Fish \& Fisheries 11: 315-340.

Gozlan, R. E., S. St-Hilaire, S. W. Feist, P. Martin \& M. L. Kent, 2005. An emergent infectious disease threatens European fish biodiversity. Nature 435: 1046.

Györe, K., 1995. Magyarország természetesvízi halai. [Freshwater fishes of Hungary] Környezetgazdálkodási Intézet, pp.1-339. (in Hungarian)

Halasi-Kovács, B., L. Antal, S. A. Nagy, 2011. First record of a Ponto-caspian Knipowitschia species (Gobiidae) in the Carpathian basin, Hungary Cybium 35: 257-258.

Harka, Á., 1997. Terjed vizeinkben a fekete törpeharcsa. [The spreadnig of black bullhead of Hungarian waters] Halászat 90 (3): 109-110. (in Hungarian)

Harka, Á. 1998. Magyarország faunájának új halfaja: az amurgéb (Perccottus glehni Dybowski, 1877). [New species for Hungarian ichtyofauna: the Amur sleeper (Perccottus glehni Dybowski, 1877)] Halászat 91 (1): 32-33. (in Hungarian) 
Harka, Á. \& Z. Sallai, 1999. Az amurgéb (Perccottus glenii Dybowski, 1877) morfológiai jellemzése, élőhelye és terjedése Magyarországon. [Morphological charcterization, habitat and spread of Amur sleeper (Perccottus glenii Dybowski, 1877) in Hungary] Halászat 92 (1), 33-36. (in Hungarian)

Harka, Á. \& Z. Sallai, 2004. Magyarország halfaunája. [The fish fauna of Hungary] Nimfea Természetvédelmi Egyesület, Szarvas, 269 pp. (in Hungarian)

Harka, Á. \& Zs. Szepesi, 2010. How many stickleback species (Gasterosteus sp.) Exist in Hungary? Pisces Hungarici 4: 101-103.

Herman, O., 1887. A magyar halászat könyve. [The book of Hungarian fisheries] Magyar Természettudományi Társulat Budapest, reprint 2008, Homonnai kiadó, 642 pp. (in Hungarian)

Herman, O., 1890. Ángolna a Balatonban és a Velenczei-tóban. [Eel in Lake Balaton and Lake Velencei] Természettudományi Közlöny 255: 603-604. (in Hungarian)

Holčík, J., 1980. Carassius auratus (Pisces) in the Danube River. Acta Scientarum Naturale Brno 14 (11): 1-43.

Jurajda, P., M. Vassilev, M. Polačik \& T. Trichkova, 2006. A first record of Perccottus glenii (Perciformes: Odontobutidae) in the Danube River in Bulgaria. Acta Zoologica Bulgarica 58: 279-282.

Kati, S., A. Mozsár, D. Árva, J. N. Cozma, I. Czeglédi, L. Antal, S. A. Nagy \& T. Erős, 2015. Feeding ecology of the invasive Amur sleeper (Perccottus glenii Dybowski, 1877) in Central Europe. International Review of Hydrobiology 100: 116-128.

Konishi, M. \& K. Takata, 2004. Size-dependent male-male competition for a spawning substrate between Pseudorasbora parva and Pseudorasbora pumila. Ichthyological Research 51: 184-187. 
Kornis, M. S., N. Mercado-Silva \& M. J. Van der Zanden, 2012. Twenty years of invasion: a review of round goby Neogobius melanostomus biology, spread and ecological implications. Journal of Fish Biology 80: 235-285.

Korponai, J., M. Braun, K. Buczkó, I. Gyulai, L. Forró, J. Nédli \& I. Papp, 2010. Transition from shallow lake to a wetland: a multi-proxy case study in Zalavári Pond, Lake Balaton, Hungary. Hydrobiologia 641: 225-244.

Koščo, J., L. Košuthová, P. Košuth \& L. Pekárik, 2010. Non-native fish species in Slovak waters: origins and present status. Biologia 65: 1057-1063.

Koščo, J., S. Lusk, K. Halačka \& V. Lusková, 2003. The expansion and occurrence of the Amur sleeper (Perccottus glenii) in eastern Slovakia. Folia Zoologia 52: 329-336.

Lawson, L. L., J. E. Hill, L. Vilizzi, S. Hardin \& G. H. Copp, 2013. Revisions of the Fish Invasiveness Scoring Kit (FISK) for its application in warmer climatic zones, with particular reference to Peninsular Florida. Risk Analysis 33: 1414-1431.

Lusk, S., V. Lusková \& L. Hanel, 2010. Alien fish species in the Czech Republic and their impact on the native fish fauna. Folia Zoologica 59: 57-72.

Mastitsky, S. E, A. Y. Karatayev, L. E. Burlakova, B. V. Adamovich, 2010. Non-native fishes of Belarus: diversity, distribution, and risk classification using the Fish Invasiveness Screening Kit (FISK). Aquatic Invasions 5: 103-114.

Mendoza, R., S. Luna, S. \& C. Aguilera, 2015. Risk assessment of the ornamental fish trade in Mexico: analysis of freshwater species and effectiveness of the FISK (Fish Invasiveness Screening Kit). Biological Invasions 17: 3491-3502.

Muskó, I. B., M. Bence \& C Balogh, 2008. Occurrence of a new Ponto-Caspian invasive species, Cordylophora caspia (Pallas, 1771) (Hydrozoa: Clavidae) in Lake Balaton (Hungary). Acta Zoologica Academiae Scientiarum Hungaricae 54: 169-179.

Nalbant, T., K. W. Battes, F. Pricope \& D. Ureche, 2004. First record of the amur sleeper 
Perccottus glenii (Pisces: Perciformes: Odontobutidae) in Romania. Travaux du Museum National d'Histoire Naturelle 47: 279-284.

Novomeská, A. \& V. Kováč, 2009. Life-history traits of non-native black bullhead Ameiurus melas with comments on its invasive potential. Journal of Applied Ichthyology 25: 79-84.

Nowak, M., W. Popek \& P. Epler, 2008. Range expansion of an invasive alien species, Chinese sleeper, (Perccottus glenii Dybowski, 1877) (Teleostei: Odontobutidae) in the Vistula river drainage. Acta Ichthyologica et Piscatoria 38: 37-40.

Onikura, N., J. Nakajima, R. I. H. Mizutani, M. K. S. Fukuda \& T. Mukai, 2011. Evaluating the potential for invasion by alien freshwater fishes in northern Kyushu Island, Japan, using the Fish Invasiveness Scoring Kit. Ichthyological Research 58: 382-387.

Paulovits, G., Á. Ferincz, Á. Staszny, A. Weiperth, I. Tátrai, J. Korponai, K. Mátyás \& N. Kováts, 2014. Long-term changes in the fish assemblage structure of a shallow eutrophic reservoir (Lake Hídvégi, Hungary), with special reference to the exotic Carassius gibelio. International Review of Hydrobiology 5: 373-381.

Pedicillo, G., A. Bicchi, V. Angeli, A. Carosi, P. Viali \& M. Lorenzoni, 2008. Growth of black bullhead Ameiurus melas (Rafinesque, 1820) in Corbara Reservoir (Umbria - Italy). Knowledge and Management of Aquatic Ecosystems 389: 05.

Peel, M. C., B. L. Finlayson \& T. A. McMahon, 2007. Updated world map of the KöppenGeiger climate classification. Hydrology and Earth System Sciences 11: 1633-1644.

Perdikaris, C., N. Koutsikos, L. Vardakas, D. Kommatas, P. Simonović, I. Paschos, V Detsis, L. Vilizzi \& G. H. Copp, G. H. 2015. Risk screening of non-native, translocated and traded aquarium freshwater fish in Greece using FISK. Fisheries Management and Ecology (doi: 10.1111/fme.12149) 
Pheloung, P. C, P. A Williams \& S. R. Halloy, 1999. A weed risk assessment model for use as a biosecurity tool evaluating plant introductions. Journal of Environmental Management 57: 239-251.

Piria, M., M. Povz, L. Vilizzi, D. Zanella, P. Simonović, G. H. Copp, 2015. Risk screening of non-native freshwater fishes in Croatia and Slovenia using the Fish Invasiveness Screening Kit. Fisheries Managment and Ecology (doi: 10.1111/fme.12147)

Povž, M. \& S. Šumer, 2006. A brief review of non-native freshwater fishes in Slovenia. Journal of Applied Ichyiology 21: 316-318.

Puntila, R., L. Vilizzi, M. Lehtiniemi \& G. H. Copp, 2013. First Application of FISK, the Freshwater Fish Invasiveness Screening Kit, in Northern Europe: Example of Southern Finland. Risk Analysis 33: 1397-1403.

R Development Core Team, 2015. R: A language and environment for statistical computing. R Foundation for Statistical Computing, Vienna, Austria. http://www.R-project.org (October 2015)

Reshetnikov, A. N., 2003. The introduced fish, rotan (Perccottus glenii), depresses populations of aquatic animals (macroinvertebrates, amphibians, and a fish). Hydrobiologia 510: 83-90.

Reshetnikov, A. N., 2004. The fish Perccottus glenii: history of introduction to western regions of Eurasia. Hydrobiologia 522: 349-350.

Reshetnikov, A. N., 2008. Does rotan Perccottus glenii (Perciformes: Odontobutidae) eat the eggs of fish and amphibians? Journal of Ichthyology 48: 336-344.

Reshetnikov, A. N. \& G. F. Ficetola, 2011. Potential range of the invasive fish rotan (Perccottus glenii) in the Holarctic. Biological Invasions 13: 2967-2980. 
Robin, X., N. Turck, A. Hainard, N. Tiberti, F. Lisacek, J. C. Sanchez \& M. Müller, 2011. pROC: an open-source package for $\mathrm{R}$ and $\mathrm{S}+$ to analyze and compare ROC curves. BMC Bioinformatics 12: 77.

Roche, K. F., M. Janač \& P. Jurajda, 2013. A review of Gobiid expansion along the DanubeRhine corridor - geopolitical change as a driver for invasion. Knowledge and Management of Aquatic Ecosystems 411: 01.

Rosecchi, E., F. Thomas \& A. J. Crivelli, 2001. Can life-history traits predict the fate of introduced species? A case study on two cyprinid fish in southern France. Freshwater Biology 46: 845-853.

Sály, P., P. Takács, I. Kiss, P. Bíró, T. Erős, 2011. The relative influence of spatial context and catchment- and site-scale environmental factors on stream fish assemblages in a human-modified landscape. Ecology of Freshwater Fish 20: 251-262.

Simonović, P., S. Maric \& V. Nikolić, 2006. Records Of Amur sleeper Perccottus glenii (Odontobutidae) in Serbia and its recent status. Archives of Biological Sciences Belgrade $58(1): 7-8$.

Simonović, P., A. Tošić, M. Vassilev, A. Apostolou, D. Mrdak, M. Ristovska, V. Kostov, V. Nikolić, D. Škraba, L. Vilizzi \& G. H. Copp, 2013. Risk assessment of non-native fishes in the Balkans Region using FISK, the invasiveness screening tool for non-native freshwater fishes. Mediterranean Marine Science 14: 369-376.

Specziár, A., 2004. Life history pattern and feeding ecology of the introduced eastern mosquitofish, Gambusia holbrooki, in a thermal spa under temperate climate, of Lake Hévíz, Hungary. Hydrobiologia 522: 249-260.

Specziár, A. \& B. Turcsányi, 2014. Effect of stocking strategy on distribution and recapture rate of common carp Cyprinus carpio L., in a large and shallow temperate lake: 
implications for recreational put-and-take fisheries management. Journal of Applied Ichthyology 30: 887-894.

Szalay, M., 1954. Új halfaj Magyarországon - ezüstkárász. [New fish species in Hungary Gible carp] Halászat 1 (3): 4. (in Hungarian)

Takács, P., T. Erős, A. Specziár, P. Sály, Z. Vitál, Á. Ferincz, T. Molnár, Z. Szabolcsi, P. Bíró \& E. Csoma, 2015. Population genetic patterns of threatened European mudminnow (Umbra krameri Walbaum, 1792) in a fragmented landscape: implications for conservation management. PLOS One 10 (9): e0138640.

Takács, P., A. Specziár, T. Erős, P. Sály, P. Bíró, 2011. A balatoni vízgyüjtő halállományainak összetétele. [Fish assemblage stuctures of the Balaton-catchment] Ecology of Lake Balaton 1: 1-21. (in Hungarian with English summary)

Tarkan, A. S., G. F. Ekmekci, L. Vilizzi \& G. H. Copp, 2014. Risk screening of non-native freshwater fishes at the frontier between Asia and Europe: first application in Turkey of the fish invasiveness screening kit. Journal of Applied Ichthyology 30: 392-398.

Terlecki, J. \& R. Palka, 1999. Occurrence of Perccottus glenii Dybowski 1877 (Perciformes, Odontobutidae) in the middle stretch of the Vistula river. Poland. Archives of Polish Fisheries 7: 141-150.

Tóth J., 1975. A brief account on the presence of the silver crucian carp (Carassius auratus gibelio Bloch 1873) in the Hungarian section of the Danube, Budapest. Annales Universitati Scientis Budapestiensis Section Biologica 18-19: 219-220.

Venkatraman, E. S., 2000. A permutation test to compare receiver operating characteristic curves. Biometrics 56: 1134-1138.

Verreycken H., G. Van Thuyne \& C. Belpaire, 2009. Nonindigenous freshwater fishes in Flanders: status, trends and risk assessment. PowerPoint presentation, Science Facing . 11 May 2009, Brussels. http://www.academia.edu/2878630/Non- 
indigenous_freshwater_fishes_in_Flanders_status_trends_and_risk_assessment accessed: 11.11.2015)

Vilizzi, L. \& G. H. Copp, 2012. Application of FISK, an invasiveness screening tool for nonnative freshwater fishes, in the Murray-Darling Basin (Southeastern Australia). Risk Analysis 33: 1432-1440.

Vutskits, Gy., 1897. A Balaton halai és gyakoriságuk. [Abundaces of fish species in Lake Balaton] Természettudományi Közlöny 29: 593-595. (in Hungarian)

Wheeler, A.C., N.R. Merrett \& D.T.G. Quigley, 2004. Additional records and notes for Wheeler's (1992) List of the common and scientific names of fishes of the British Isles. Journal of Fish Biology 65 (Supplement B): 1-40.

Youden, W.J., 1950. Index for rating diagnostic tests. Cancer 3: 32-35.

Zlinszky, A. \& G. Tímár, 2013. Historic maps as a data source for socio-hydrology: a case study of the Lake Balaton wetland system, Hungary. Hydrology And Earth System Sciences 17: 4589-4606. 


\section{Tables}

Table 1. Fish species assessed with FISK v2 for the Balaton-catchment. For each species, a priori invasiveness (as per http://www.issg.org/ and http://www.fishbase.org) and protection status, along with corresponding FISK score and certainty factor (CF), are reported. Outcome is based on a calibration threshold of 11.75 between medium and high risk species sensu lato. Criterion: 1 = already occurring in the catchment; 2 = not reported from the catchment yet, but occurring within the territory of Hungary (see text for computations).

\begin{tabular}{|c|c|c|c|c|c|c|c|c|c|c|c|c|c|}
\hline \multirow[b]{2}{*}{ Species name } & \multirow[b]{2}{*}{ Common name } & \multirow[b]{2}{*}{ Origin } & \multirow[b]{2}{*}{$\begin{array}{l}\text { Invasiveness/ } \\
\text { Protection Status }\end{array}$} & \multirow[b]{2}{*}{ Criterion } & \multicolumn{5}{|l|}{ Score } & \multicolumn{4}{|c|}{ Certainty Factor } \\
\hline & & & & & Mean & Min & Max & $\mathrm{SE}$ & Outcome & Mean & Min & Max & $\mathrm{SE}$ \\
\hline Ameiurus melas & black bullhead & $\begin{array}{l}\text { North- } \\
\text { America }\end{array}$ & $\begin{array}{l}\text { Invasive/Not } \\
\text { evaluated }\end{array}$ & 1 & 29.00 & 25.0 & 33.0 & 2.31 & $\mathrm{H}$ & 0.87 & 0.8 & 0.9 & 0.03 \\
\hline Ameiurus nebulosus & brown bullhead & North America & $\begin{array}{l}\text { Invasive/Least } \\
\text { concern }\end{array}$ & 1 & 23.00 & 16.0 & 30.0 & 6.42 & MH & 0.82 & 0.8 & 0.9 & 0.27 \\
\hline Anguilla anguilla & European eel & Europe & $\begin{array}{l}\text { Non-Invasive/ } \\
\text { Critically } \\
\text { Endangered }\end{array}$ & 1 & 15.25 & 14.0 & 17.0 & 0.75 & MH & 0.88 & 0.9 & 0.9 & 0.01 \\
\hline Archrocentrus multispinosus & rainbow cichlid & South America & $\begin{array}{l}\text { Non-invasive/Not } \\
\text { evaluated }\end{array}$ & 2 & 7.00 & 3.0 & 16.0 & 3.02 & M & 0.88 & 0.8 & 0.9 & 0.04 \\
\hline Babka gymnotrachelus & racer goby & Ponto-Caspian & $\begin{array}{l}\text { Non-invasive/Least } \\
\text { concern }\end{array}$ & 2 & 17.50 & 14.0 & 20.0 & 1.32 & MH & 0.88 & 0.9 & 0.9 & 0.03 \\
\hline Clarias gariepinus & North African catfish & North Africa & $\begin{array}{l}\text { Invasive/Least } \\
\text { concert }\end{array}$ & 2 & 12.63 & 5.0 & 18.0 & 2.78 & MH & 0.81 & 0.8 & 0.9 & 0.04 \\
\hline Ctenopharyngodon idella & grass carp & Far-East & $\begin{array}{l}\text { Non-Invasive/Not } \\
\text { evaluated }\end{array}$ & 1 & 17.63 & 12.0 & 23.0 & 2.36 & $\mathrm{MH}$ & 0.83 & 0.8 & 0.9 & 0.03 \\
\hline Gambusia holbrooki & eastern mosquitofish & $\begin{array}{l}\text { North- } \\
\text { America }\end{array}$ & $\begin{array}{l}\text { Invasive/Not } \\
\text { evaluated }\end{array}$ & 1 & 11.50 & 7.0 & 14.5 & 1.67 & $\mathrm{H}$ & 0.84 & 0.7 & 0.9 & 0.08 \\
\hline Gasterostus aculeatus & threespine stickleback & Europe & $\begin{array}{l}\text { Non-invasive/Least } \\
\text { concern }\end{array}$ & 2 & 11.13 & 4.5 & 17.0 & 2.63 & M & 0.79 & 0.7 & 0.8 & 0.26 \\
\hline
\end{tabular}




\begin{tabular}{|c|c|c|c|c|c|c|c|c|c|c|c|c|c|}
\hline $\begin{array}{l}\text { Hypophthalmichthys molitrx } \\
x \text { H. nobilis }\end{array}$ & Asian carp hybrid & Far-East & $\begin{array}{l}\text { Invasive/Near } \\
\text { threatened }\end{array}$ & 1 & 23.38 & 6.0 & 21.0 & 3.33 & MH & 0.85 & 0.6 & 0.9 & 0.07 \\
\hline Ictalurus punctatus & channel catfish & $\begin{array}{l}\text { North- } \\
\text { America }\end{array}$ & $\begin{array}{l}\text { Invasive/Least } \\
\text { concern }\end{array}$ & 2 & 8.67 & 4.0 & 15.0 & 2.33 & M & 0.78 & 0.8 & 0.9 & 0.26 \\
\hline Ictiobus bubalus & smallmouth buffalo & $\begin{array}{l}\text { North- } \\
\text { America }\end{array}$ & $\begin{array}{l}\text { Non-invasive/Least } \\
\text { concern }\end{array}$ & 2 & 13.63 & 11.0 & 26.0 & 3.14 & $\mathrm{MH}$ & 0.74 & 0.7 & 0.9 & 0.07 \\
\hline Knipowitshia caucasica & Caucasian dwarf goby & Ponto-Caspian & $\begin{array}{l}\text { Non-invasive/Least } \\
\text { concern }\end{array}$ & 2 & 10.25 & 7.0 & 20.0 & 2.43 & M & 0.81 & 0.8 & 1.0 & 0.03 \\
\hline Lepomis gibbosus & pumpkinseed & $\begin{array}{l}\text { North- } \\
\text { America }\end{array}$ & $\begin{array}{l}\text { Non-Invasive/Not } \\
\text { evaluated }\end{array}$ & 1 & 19.25 & 8.0 & 22.0 & 3.50 & $\mathrm{MH}$ & 0.81 & 0.8 & 0.9 & 0.05 \\
\hline Micropterus salmoides & largemouth bass & $\begin{array}{l}\text { North- } \\
\text { America }\end{array}$ & $\begin{array}{l}\text { Invasive/Least } \\
\text { concern }\end{array}$ & 2 & 12.75 & 10.0 & 20.0 & 2.95 & MH & 0.87 & 0.7 & 1.0 & 0.06 \\
\hline Mylopharyngodon piecus & black carp & Far-East & $\begin{array}{l}\text { Invasive/Data } \\
\text { deficient }\end{array}$ & 2 & 15.38 & 20.5 & 26.0 & 2.88 & MH & 0.83 & 0.8 & 1.0 & 0.03 \\
\hline Neogobius fluviatilis & monkey goby & Ponto-Caspian & $\begin{array}{l}\text { Non-Invasive/Not } \\
\text { evaluated }\end{array}$ & 1 & 14.88 & 8.0 & 17.0 & 2.11 & MH & 0.85 & 0.6 & 1.0 & 0.08 \\
\hline Neogobius melanostomus & round goby & Ponto-Caspian & $\begin{array}{l}\text { Invasive/Least } \\
\text { concern }\end{array}$ & 2 & 22.38 & 5.0 & 19.5 & 1.25 & $\mathrm{MH}$ & 0.87 & 0.8 & 1.0 & 0.06 \\
\hline Oncorhynchus mykiss & rainbow trout & $\begin{array}{l}\text { North- } \\
\text { America }\end{array}$ & $\begin{array}{l}\text { Invasive/Not } \\
\text { evaluated }\end{array}$ & 1 & 12.00 & 23.0 & 27.0 & 1.96 & MH & 0.79 & 0.7 & 1.0 & 0.09 \\
\hline Oreochromis niloticus & Nile tilapia & North-Africa & $\begin{array}{l}\text { Invasive/Not } \\
\text { Evaluated }\end{array}$ & 1 & 12.88 & 14.5 & 24.0 & 3.04 & MH & 0.88 & 0.8 & 1.0 & 0.06 \\
\hline Percottus glenii & Amur (Chinese) sleeper & Far-East & $\begin{array}{l}\text { Non-Invasive/ } \\
\text { Vulnerable }\end{array}$ & 1 & 24.50 & 5.0 & 19.0 & 0.87 & MH & 0.88 & 0.8 & 0.9 & 0.07 \\
\hline Ponticola kessleri & Kessler's goby & Ponto-Caspian & $\begin{array}{l}\text { Non-invasive/Least } \\
\text { concern }\end{array}$ & 2 & 18.25 & 21.0 & 30.0 & 2.15 & MH & 0.89 & 0.9 & 0.9 & 0.05 \\
\hline Proterorhinus marmoratus & tubenose goby & Ponto-Caspian & $\begin{array}{l}\text { Non-Invasive/ Least } \\
\text { concern }\end{array}$ & 1 & 11.50 & 7.0 & 11.0 & 2.90 & MH & 0.85 & 0.8 & 0.8 & 0.04 \\
\hline Pseudorasbora parva & topmouth gudgeon & Far-East & $\begin{array}{l}\text { Invasive/Not } \\
\text { evaluated }\end{array}$ & 1 & 25.00 & 6.0 & 21.0 & 1.96 & $\mathrm{H}$ & 0.85 & 0.6 & 0.9 & 0.00 \\
\hline
\end{tabular}


Table 2. $P$ values for Venkatraman's permutaton tests comparing the AUCs of the four ROC curves from the four independent assessments.

\begin{tabular}{l|llll} 
Assessor & AF & AS & AW & PT \\
\hline AF & - & 0.283 & 0.875 & 0.633 \\
AS & & - & 0.709 & 0.205 \\
AW & & & - & 0.216 \\
PT & & & \multicolumn{2}{c}{-}
\end{tabular}


Figure legends

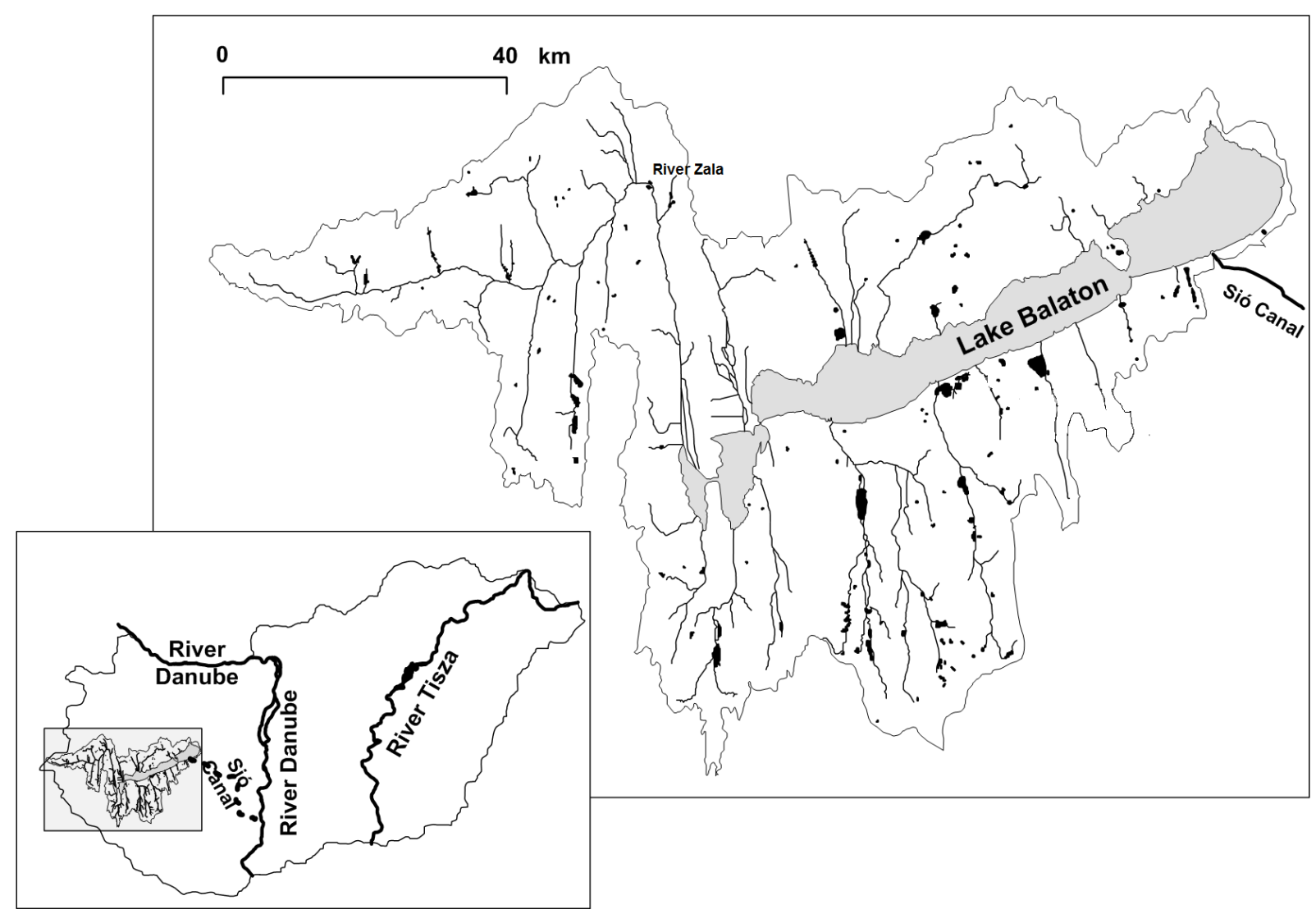

Figure 1. Map of the Balaton catchment (Hungary), with indication of the main inflow (River Zala) and outflow (Sió Canal) 

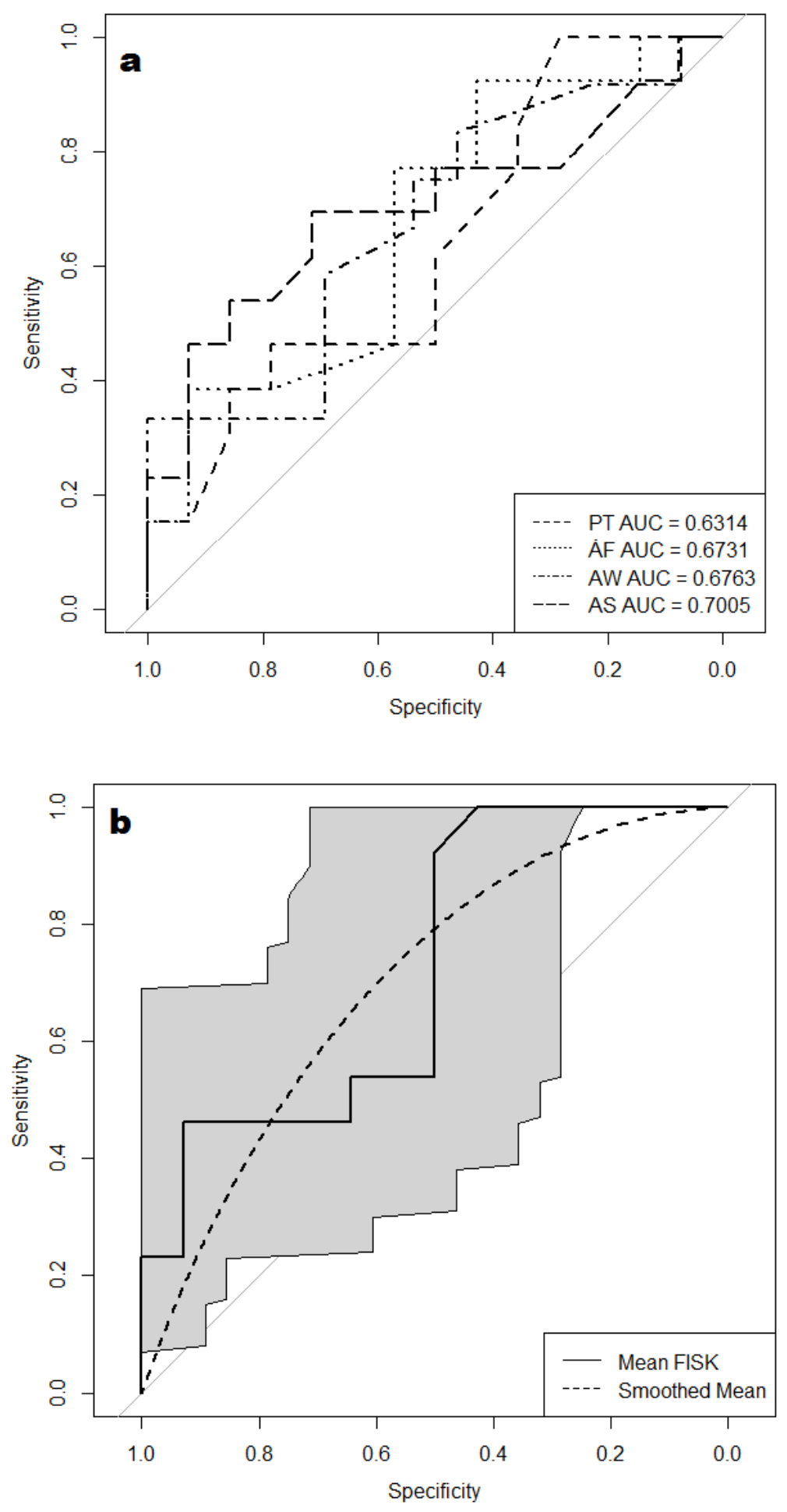
Figure 2. (a) Receiver operating characteristic (ROC) curves for two assessors (AF, AS, AW and PT) on 26 fish species assessed by FISK for the Balaton-catchment. (b) Mean ROC curve based on mean scores from the four assessors, with smoothing line and confidence intervals of specificities (see Table 1).

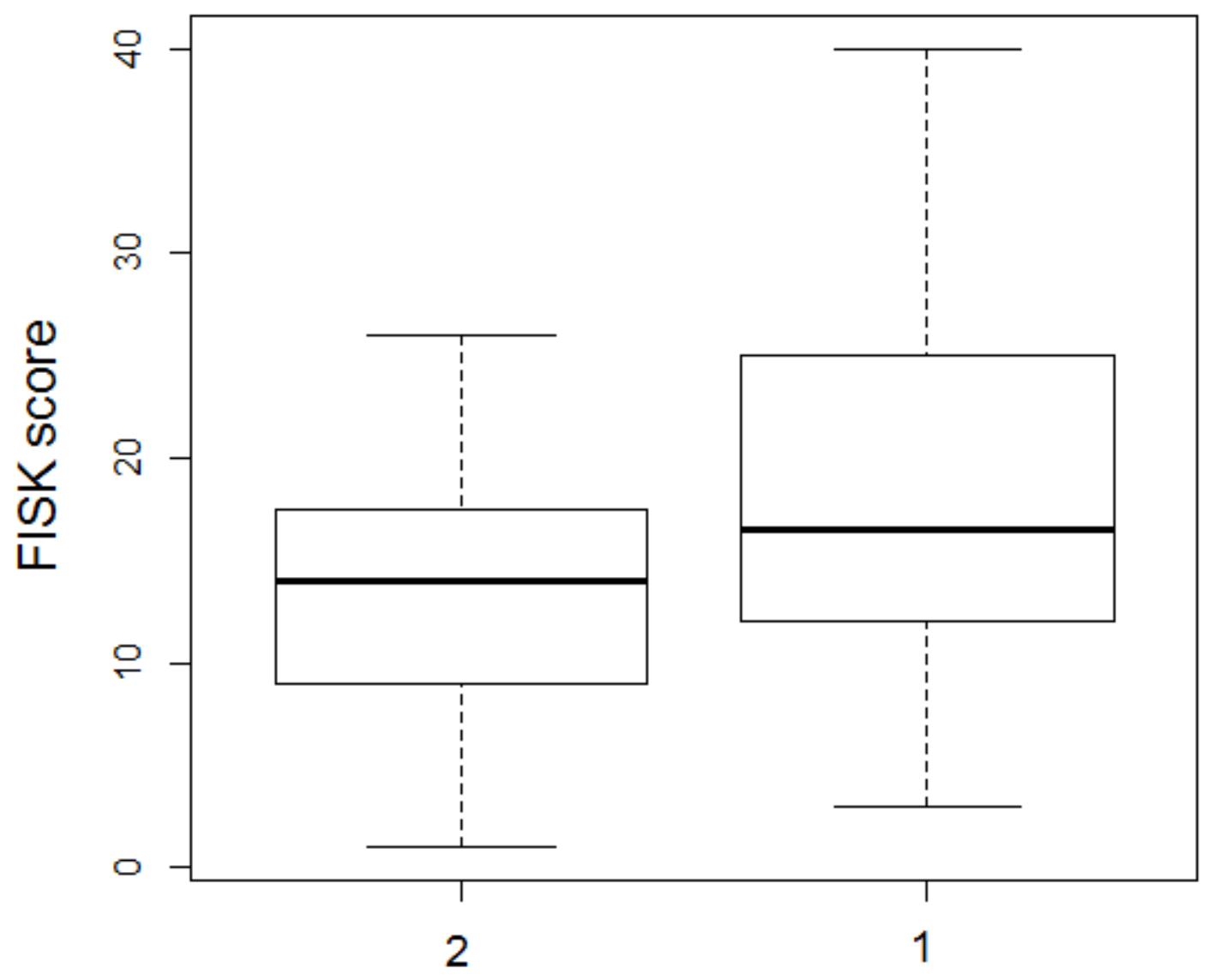

Criterion 
Figure 3. Boxplots of mean FISK scores according to species' selection criteria: $1=$ already occurring in the catchment; 2 = not yet reported from the catchment, but occurring within the territory of Hungary.

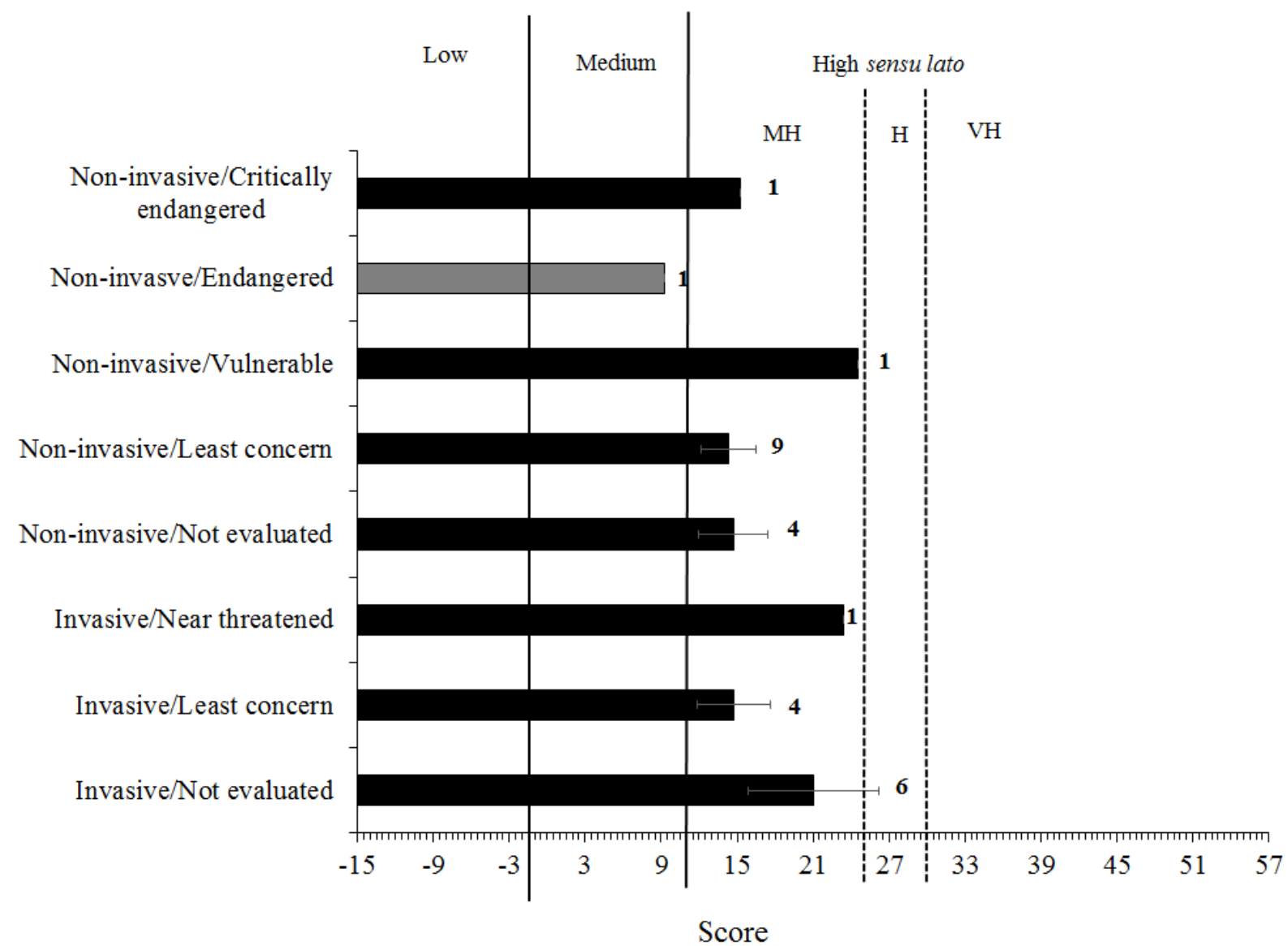

Figure 4. Mean scores ( \pm SE and $n$ ) for 26 fish species assessed by FISK for the Balatoncatchment and ranked according to their a priori invasiveness and protection status (cf. Table 1). Thresholds are: $<1$ (low risk) and $\geq 11.375$ (high risk sensu lato), with medium risk species in between. Risk categories and [lower, upper] scores are: $\mathrm{L}=$ low risk $[-15,1[; \mathrm{M}=$ medium risk $[1,11.375[; \mathrm{MH}=$ moderately high risk $[11.375,25[; \mathrm{H}=$ high risk $[25,30[; \mathrm{VH}=$ very high risk $[30,57]$. 
